\title{
GEMBALA SIDANG SEBAGAI PENGAJAR MENURUT TIMOTIUS DAN TITUS
}

\author{
Dr. Malik, M.Th. \\ Sekolah Tinggi Teologi Injili Arastamar (SETIA) Jakarta \\ malikbambangan@sttsetia.ac.id
}

\begin{abstract}
Abstrak
Peranan gembala sidang dalam jemaat sangat menentukan pertumbuhan iman jemaat tersebut. Oleh sebab itu sangat diperlukan kinerja yang dapat memberi manfaat kepada anggota jemaatnya. Dalam hal ini gembala sidang memiliki peran penting untuk memberikan pertumbuhan iman kepada setiap anggota jemaatnya. Gembala sidang berperan penting untuk memberikan pastoralia kepada jemaat, namun juga bertindak sebagai pengajar bagi anggota jemaatnya. Tujuan peneletian ini adalah untuk menemukan peran gembala sidang yang juga sebagai pengajar bagi jemaat menurut kitab Timotius dan Titus. Metode yang digunakan adalah dengan mengumpulkan data-data literatur melalui studi dari sumbersumber yang berhubungan dengan maksud penelitian ini. Hasil dari penelitian ini adalah gembala sidang memiliki peran ganda yakni; sebagai gembala sidang dan pengajar bagi jemaat menurut kitab Timotius dan Titus. Kesimpulan dari penelitian ini adalah gembala sidang selain melaksanakan pastoralia bagi jemaat, juga berperan sebagai pengajar dalam memberikan pertumbuhan iman bagi anggota jemaatnya.
\end{abstract}

\section{Kata Kunci: Gembala Sidang, Pengajar, Pastoralia, Timotius, Titus}

\section{A. PENDAHULUAN}

Banyak orang percaya tidak mengerti akan apa yang disebut penggembalaan, dengan demikian mereka juga tidak mengetahui akan tugas dan tanggungjawab mereka selaku domba-domba Yesus Kristus. Teologi penggembalaan ini sering juga disebut sebagai teologi Pastoral.Banyak juga orang Kristen yang nota bene sebagai domba-domba Yesus Kristus, namun mereka tidak mengenal siapa gembala mereka. Raja Daud sangat jelas memberikan rincian hubungan yang indah dan manis antara gembala dengan domba-dombanya. Dalam Mazmur 23 sangat jelas pernyataan Daud jika Tuhan adalah gembalanya dan Daud adalah domba-Nya.Begitu dekatnya hubungan antara gembala dengan domba sehingga domba merasakan ketenangan dalam hidupnya. Sang gembala Agung segala domba sangat mengerti akan kehidupan domba-domba-Nya. Setiap orang percaya wajib hidup dan bertumbuh menurut ajaran Kristus. Oleh sebab itu perlu selalu ada pembaharuan dalam pelayanan kepada jemaat. Untuk hidup dalam proses pembaharuan tersebut, maka sebagai orang percaya, Tuhan mengangkat para rasul, pemberita Injil, para pengajar dan gembala untuk memperlengkapi orangorang Kudus agar bertumbuh mencapai kedewasaan penuh di dalam Kristus Yesus (Ef. 4:11-13). 
Lalu bagaimana dengan kehidupan orang percaya dalam dunia perjanjian Baru, khususnya zaman pelayanan Paulus? Bagaimana konsep rasul Paulus dalam memahami tentang arti pentingnya penggembalaan itu? Lalu prinsip apa yang digunakan Paulus dalam penggembalaan yang ia lakukan dalam Pelayanannya?

\section{B. METODE PENELITIAN}

Metode penelitian yang digunakan peneliti dalam penelitian ini adalah kualitatif dengan menggunakan pendekatan biblikal melalui studi pustaka tentang peran gembala sidang yang juga sebagai pengajar berdasarkan kajian teologis dalam surat Paulus kepada Timotius dan Titus. Dengan demikian akan didapatkan suatu hasil bahwa gembala sidang tidak hanya bertugas dalam penggembalaan saja, namun juga sebagai pengajar Alkitab bagi anggota jemaatnya.

\section{PEMBAHASAN}

\section{Definisi dan Pengertian Gembala sidang}

Dalam Kamus Besar Bahasa Indonesia, istilah "gembala" diartikan sebagai penjaga atau pemiara mahluk hidup, selain itu juga dapat diartikan sebagai penjaga keselamatan orang banyak. Dalam bahasa Inggris, kata "shepherd" (gembala) berakar dari kata "sheep" (domba). Tetapi dalam bahasa Ibrani kuno, kata "gembala" tidak berakar dari kata "domba", melainkan dari kata "memberi makan." Kata Ibrani untuk "gembala" ialah "ra'ah." Kata ini dibentuk dari kata "memberi makan." Akibatnya, gembala dikenal sebagai "orang yang memberi makan."1 Dua fungsi dari pekerjaan gembala yang dijelaskan dalam Alkitab ialah memelihara dan melindungi kawanan domba gembalaannya. Beradasarkan pengertian ini jugalah yang mungkin dijadikan dasar bagi para pendeta jemaat disebut sebagai gembala jemaat (gembala sidang).

\section{Gembala di dalam Alkitab}

Berikut ini kita akan melihat beberapa hal yang termuat dalam Alkitab, baik dalam Perjanjian Lama dan Perjanjian Baru mengenai sosok gembala, antara lain:

\subsection{Gembala di dalam Perjanjian Lama}

a. Celakalah Gembala yang memberi makan dirinya sendiri (Yeh. 34:13). Pesan dari Yehezkiel 34 merupakan pernyataan utama dari perspektif Perjanjian Lama mengenai penggembalaan. Mereka yang memimpin bangsa Yehuda mempunyai fungsi penggembala. Hal ini termasuk para penguasa mau pun pemimpin agama; keduanya bertanggung jawab untuk memelihara bangsa.Tekanannya pada pemeliharaan rohani dari umat Allah. Dalam ayat 2, ada teguran dan dakwaan terhadap para gembala.Para gembala bangsa bersalah atas satu dosa yang tampak jelas, yaitu memberi makan diri sendiri bukannya memberi makan dombanya.

\footnotetext{
${ }^{1}$ Oliver Mc Mahan, Gembala Jemaat yang Sukses, (Jakarta : Sinode GBI, 2002), 5.
} 
b. Campur tangan Tuhan bagi kawanan domba yang terlantar (Yehezkiel 34:10b). Para gembala bisa saja beranggapan bahwa kawanan domba itu milik mereka sehingga diperlakukan seenaknya saja.Allah menegaskan siapa pemilik domba-domba itu sesungguhnya. Mereka adalah milik-Nya sendiri yang istimewa. Pada saat seorang gembala terlalu memperhatikan kebutuhannya sendiri sehingga mengabaikan dan menganiaya kawanan dombanya, ia secara sadar mau pun tak sadar mulai mengambil keuntungan dari mereka.

2.2 Gembala di dalam Perjanjian Baru

a. Gembala sejati (Yoh.10:1-6). Sebagaimana domba-domba mengenali suara Sang Gembala Utama, demikianlah jemaat seharusnya mempunyai keyakinan teguh kepada masing-masing gembala jemaatnya. Pengadaan fasilitas dan aktivitas gerejawi bukanlah aspekaspek penting dari pelayanan gereja, melainkan hubungan pribadi yang dekat antara gembala dengan jemaatnya.

b. Gembala penjaga (Yoh.10:7-18). Ancaman bahaya yang paling menakutkan dari kawanan domba tanpa penjagaan dari gemabalanya adalah bahaya pembunuhan dari hewan-hewan buas yang ada di sekelilingnya, dibandingkan ancaman kelaparan.Karakter gembala sejati menjadikannya seorang gembala penjaga. Dialah yang menjamin fungsi perlindungan.

c. Kawanan domba mengenal gembala yang sejati (Yoh.10:1929). Hanya domba yang mengenal suara Gembala Utama yang dapat menerima pemeliharaan penggembalaan-Nya. Sebagian orang Yahudi menginginkan pemeliharaan itu. Namun, karena ketidakpercayaan mereka, perpecahan dan kebingungan terus berlanjut di antara mereka. Akibatnya, mereka tidak menerima pemeliharaan Gembala Utama. Demikian juga orang di gereja tidak dapat menerima pemeliharaan pastoral jika mereka tidak percaya penuh kepada kuasa dan karya Tuhan Yesus.

Begitu pentingnya, para gembala ini didalam Yohanes 21: 15-17, sampai-sampai Tuhan Yesus 3 (tiga) kali memerintahkan Petrus: "Gembalakanlah domba-domba Ku." Kalimat ini diucapkan tiga kali oleh Yesus dengan tujuan untuk mempertegas kepada Petrus dan muridmurid yang lain akan tugas penting seorang gembala tersebut demikian pentingnya untuk dilaksanakan. Dalam proses pertumbuhan kita sebagai orang Kristen, gembala bertugas memperlengkapi kita. Dalam Efesus 4: 11-13 Paulus menuliskan demikian; "Dan Ialah yang memberikan baik rasul-rasul maupun nabi-nabi, baik pemberitapemberita Injil maupun gembala-gembala dan pengajar-pengajar, untuk memperlengkapi orang-orang kudus bagi pekerjaan pelayanan, bagi pembangunan tubuh Kristus, sampai kita semua telah mencapai kesatuan iman dan pengetahuan yang benar tentang Anak Allah, 
kedewasaan penuh, dan tingkat pertumbuhan yang sesuai dengan kepenuhan Kristus"

\section{Definisi Pengajar (guru)}

Definisi guru adalah orang yang pekerjaannya, mata pencahariannya dan profesinya sebagai mengajar. ${ }^{2}$ Jika berangkat dari pemahaman tersebut, bahwa guru adalah merupakan mata pencaharian dan profesi, maka sangat tepat jika menjadi seorang guru itu adalah suatu pekerjaan. Jika menjadi guru merupakan suatu pekerjaannya, profesinya dan mata pencahariannya, maka dia akan focus dan tekun dalam pekerjaan tersebut. Bukankah hal yang demikian juga terdapat dalam diri dan pribadi seorang gembala sidang?Dengan melihat berbagai peran daripada seorang guru, maka dapat dipastika jika guru memiliki peran ganda untuk melaksanakan tugasnya dalam mengajar.Sidjabat menuliskan beberapa peran guru demikian, guru sebagai pemberita Injil, sebagai imam, sebagai gembala, sebagai konselor dan sebagai teolog. ${ }^{3} \mathrm{Oleh}$ sebab itu berdasarkan beberapa pengertian dari definisi tersebut di atas, maka dalam tulisan ini menjadikan topic bahwa gembala sidang adalah juga sebagai pengajar dalam jemaat.

\section{Definisi Pendidikan}

Kata pendidikan berasal dari kata didik, yang memiliki arti sebagai memelihara, merawat, dan memberi latihan agar seseorang memiliki ilmu pengetahuan seperti yang diharapkan contohnya, sopan santun, akal budi, dan akhlak. ${ }^{4}$ Lebih rinci dituliskan oleh Thomas H. Groome dalam mengutip pendapat Lawrence Cremin yang mendefinisikan pendidikan sebagai usaha sengaja, sistematis, dan terus menerus untuk menyampaikan, menimbulkan, atau memperoleh pengetahuan, sikap-sikap, nilai-nilai, keahlian-keahlian, atau kepekaan-kepekaan, juga setiap akibat dari usaha itu. ${ }^{5}$ Jika dipandang dari sisi iman Kristen maka, mendidik merupakan panggilan Allah bagi setiap umat-Nya. Karena itu Musa menuliskan kepada bangsa Israel tentang tugas dan tanggung jawab orang tua terhadap keluarga untuk melangsungkan pendidikan di manapun mereka berada (Ul. 6:4-9). Pendidikan itu tidak memandang usia bagi semua pesertanya. Pendidikan itu dimulai sejak lahir sampai mati. Pendidikan merupakan suatu proses pembelajaran yang berlangsung seumur hidup dalam setiap orang. Kata pendidikan mempunyai arti sebagai proses pengubahan sikap dan tata laku seseorang atau kelompok orang dalam usaha mendewasakan manusia melalui upaya pengajaran dan pelatihan, proses, perbuatan, dan cara mendidik. ${ }^{6}$ Jadi pendidikan adalah suatu upaya untuk melakukan tindakan nyata bagi murid untuk dapat melakukannya. Pengajaran, pelatihan merupakan proses untuk pendewasaan intelektual serta moral dan etika bagi setiap murid.

\section{Pendidikan Kristen}

\footnotetext{
${ }^{2}$ Tim Penyusun KBBI-III, (Jakarta: Balai Pustaka, 2002), 377.

${ }^{3}$ B.S. Sidjabat, Menjadi Guru Profesional, (Bandung: Kalam Hidup, 2000), 40

${ }^{4}$ Daryanto S.S., Kamus Bahasa Indonesia Lengkap, (Surabaya: Apollo, 1997), 168.

${ }^{5}$ Thomas H. Groome, Christian Religious Education, (Jakarta: BPK Gunung Mulia, 2011), 29

${ }^{6}$ Daryanto S.S., Kamus Bahasa, 168.
} 
Pendidikan Kristen merupakan cakupan pelayanan yang sangat luas. Cakupan pendidkan Kristen tidak hanya terbatas pada orang Kristen, namun tertuju kepada semua orang. Itu artinya bahwa pendidikan Kristen tidak berada pada posisi inklusif namun eksklusif. Pendidikan Kristen merupakan wadah khusus untuk menjangkau manusia secara umum. Khoe Yao Tung menjelaskan bahwa pendidikan Kristen adalah memuridkan, menggerakkan anak-anak dekat dengan Tuhan. Mendidik anak dalam Kristus adalah mendidik dalam kepemimpinan yang spiritual. ${ }^{7}$ Dapat dipastikan bahwa pendidikan Kristen itu bersifat rohani, dimana membawa setiap murid-murid yang didik untuk mengikuti ajaran Kristen sebagaimana yang tertulis dalam Alkitab. Pendidikan Kristen akan berdampak positif bagi setiap murid karena pembentukan karakter yang rohani ditanamkan dalam pengajaran ini. Bagi para pendidik Kristen sangat berperan penting dalam mengisi hati dan pikiran serta jiwa para muridnya dengan Firman Tuhan.

Berbicara mengenai pendidikan Kristen tidak hanya melulu kepada tugas dan tanggung jawab guru agama Kristen, namun lebih mengarah kepada semua pemimpin Kristen yang mengajar umat Tuhan dengan kebenaran Firman Tuhan. Dengan demikian pendidikan Kristentidak hanya dapat berlaku di lingkungan formal seperti di sekolah, namun bisa juga berlaku di luar sekolah, misalnya di gereja, rumah atau tempat lain yang bisa dipergunakan untuk mengajarkan Alkitab. Pola pengajaran bagi anak-anak Yahudi dimulai juga di rumah kemudian secara resmi di Sinagoge. Hal ini mengandung arti bahwa pendidikan Kristen itu juga merupakan tanggung jawab orang tua berdasarkan Ulangan 6:6-9. Sangat disayangkan karena "dewasa ini banyak orang tua Kristen yang tidak mau melakukan tugas ini." Semuanya diserahkan kepada guru agama dan gembala sidang untuk mengajar anak-anak mereka.

\section{Latar belakang $1 \&$ II Timotius dan Titus}

Surat 1 dan 2 Timotius dan Titus biasanya disebut sebagai Surat-Surat Penggembalaan, di mana surat-surat ini adalah surat-surat dari Paulus (1 Tim. 1:1; 2 Tim. 1:1; Tit. 1:1). Kepada Timotius (di Efesus) dan Titus (di Kreta) mengenai pelayanan pastoral di gereja. Beberapa pengeritik telah mempersoalkan kepenulisan Paulus atas surat ini, namun gereja mula-mula dengan tegas menempatkannya sebagai surat-surat Paulus yang asli. Walaupun ada perbedaan gaya penulisan dan kosakata dalam Surat-Surat Penggembalaan dibanding dengan surat kiriman lain dari Paulus, usia lanjut dan perhatian pribadi Paulus terhadap pelayanan Timotius dan Titus dapat menerangkan perbedaan ini dengan cukup menyakinkan. Namun belakangan pada akhrinya surat Filemon juga dimasukkan sebagai surat penggembalaan Paulus.

Paulus menulis surat 1 Timotius sesudah peristiwa-peristiwa yang tercantum dalam pasal terakhir Kisah Para Rasul. Hukuman penjara yang pertama kali dialami Paulus di Roma (Kis. 28:1-30) rupanya berakhir dengan kebebasan (2 Tim. 4:16-17). Setelah itu, menurut keterangan Klemens dari Roma (sekitar tahun 96

\footnotetext{
${ }^{7}$ Khoe Yao Tung, Terpanggil Menjadi Pendidik Kristen yang Berhati Gembala, (Yogyakarta:
} ANDI, 2016), 2 
M) dan Kanon Muratori (sekitar tahun 170 M), Paulus meninggalkan Roma menuju ke arah barat ke Spanyol dan di sana melaksanakan pelayanan yang sudah lama dicita-citakannya (bdk. Rm. 15:23-24,28).

Berdasarkan data dalam surat-surat Penggembalaan ini, Paulus kemudian kembali ke daerah Laut Aegea (khususnya Kreta, Makedonia, dan Yunani) untuk pelayanan selanjutnya.Sementara waktu ini (sekitar tahun 64-65 M), Paulus menugaskan Timotius sebagai wakil rasuli untuk melayani di Efesus, dan Titus di Kreta. Dari Makedonia, Paulus menulis surat yang pertama kepada Timotius, dan beberapa waktu kemudian dia menulis kepada Titus. Setelah itu, Paulus kembali ditawan di Roma, ketika dia menulis surat yang kedua kepada Timotius, tidak lama sebelum dia mati syahid pada tahun 67 atau 68 M (lih. 2 Tim. 4:6-8).

\section{Gembala sebagai Pengajar berdasarkan Timotius dan Titus}

\section{a. Tugas seorang Gembala dalam Timotius}

Untuk memahami dan mencermati arti dari gembala sebagai pengajar, maka menurut Peter Wongso, guru adalah orang yang mengajarkan Firman Tuhan dan kebenaran Alkitab kepada orang Kristen. Firman Tuhan sendiri merupakan pengajaran (2 Tim.3:16). Oleh sebab itu hamba Tuhan harus mementingkan pengajaran (2 Tim. 2:24) yakni yang cakap mengajar orang lain. ${ }^{8}$ Gembala harus menanamkan ke dalam jemaatnya semangat dan penglihatan pemberitaan Injil. Sebagaimana Kristus mengajar murid-murid-Nya untuk mengangkat mata mereka dan melihat ke ladang tuaian, demikianlah Ia menghendaki agar gembala-gembala bawahan-Nya akan mengajarkan hal yang serupa kepada jemaatnya. ${ }^{9}$ Para rasul Kristus kini telah tiada dan yang menduduki posisi sebagai pengajar dalam hirarki kepemimpinan Kristus secara struktural adalah penilik jemaat, penatua dan diaken yakni gembala sidang pada masa kini. Landasan alkitabiahnya adalah jelas berdasarkan surat Paulus kepada Timotius dan Titus bahwa para penilik dan penatua serta diaken inilah yang ditetapkan untuk bertanggungjawab dalam tiaptiap jemaat (I Tim.1:18; Tit.1:5)

Tugas yang pertama diterima oleh Timotius selaku gembala sidang di Efesus adalah dalam I Timotius 1:3 'Ketika aku hendak meneruskan perjalananku ke wilayah Makedonia, aku telah mendesak engkau supaya engkau tinggal di Efesus dan menasehatkan orang-orang tertentu, agar mereka jangan mengajarkan ajaran lain.' Dalam hal ini Timotius sebenaranya memiliki posisi kecakapan yang tinggi dalam jemaat untuk mengawasi para pengajar-pengajar dalam jemaat (I Tim.1:411). Itulah sebabnya Paulus dengan iman memberikan tugas ini kepada Timotius untuk dikerjakan dengan iman dan hati nurani yang murni (I Tim.1:18). Timotius mendapat tugas dalam jemaat di Efesus untuk menghadapi pengajar-pengajar sesat yang siap memasuki jemaat yang sudah mereka dirikan itu (I Tim. 4:1-16; II Tim. 2:14-26; II Tim. 4:2-5; II Tim.4:14-15). Dalam pelaksanaan tugas ini, Timotius mendapat otoritas ilahi dan integritas penuh dalam melayani meskipun masih muda (I Tim.4:11-16; II Tim. 1:7; 3:14-15). Otoritas dan integritas dalam mengajar selaku gembala sidang di Efesus bagi Timotius hal itu telah dia terima melalui

\footnotetext{
${ }^{8}$ Peter Wongso, Theologia Penggembalaan, (Malang: Literatur SAAT, 2007), 7-18

${ }^{9}$ Ralph M. Riggs, Gembala Sidang Yang Berhasil, (Malang:Gandum Mas, 2003), 76
} 
pengajaran dan pendidikan sejak kecil dalam keluarganya.Jadi adalah sangat wajar jika Timotius ini ditetapkan sebagai gembala sidang di Efesus yang juga adalah pengajar yang handal dan beintegritas. Ditambah lagi dengan apa yang ia terima dari penumpangan tangan para penatua dalam pelaksanaan tugas ini. "Tugas ini kuberikan kepadamu, Timotius anakku, sesuai dengan apa yang telah dinubuatkan tentang dirimu, supaya dikuatkan oleh nubuat itu engkau memperjuangkan perjuangan yang baik dengan iman dan hati nurani yang murni (I Tim.1:18). Jangan lalai dalam mempergunakan karunia yang ada padamu, yang telah diberikan kepadamu oleh nubuat dan dengan penumpangan tangan sidang penatua (I Tim.4:14).

Ralph M.Riggs, menyatakan bahwa seorang pendeta perlu mendapat pendidikan, pengalaman-pengalaman rohani yang pokok dan harus mempunyai pengetahuan yang lengkap akan Firman Allah. ${ }^{10}$ Jadi sudah jelas bahwa seorang gembala sidang itu sangat perlu memperlengkapi diri sedini mungkin untuk pelayanan ke depan. Adalah bukan secara kebetulan jika Paulus sudah terdidik dari sejak kanak-kanak dalam keluarga Yahudi sehingga sampai dewasa dia juga mahir karena mengikuti pendidikan Alkitab sampai ke jenjang yang lebih tinggi yakni menjadi anggota Sanhedrin murid Gamaliel. Begitu juga Timotius yang sudah belajar sejak kecil dari neneknya Louis dan ibunya Eunike (2T im.1:5).

Dalam pengembangan iman jemaat yang dilayani oleh Paulus bersama dengan Timotius, memiliki suatu mata rantai kepemimpinan yang solid. Ketika Paulus tidak berada ditempat yang sudah mereka layani Paulus menetapkan Timotius dan Titus anak rohaninya dengan tujuan untuk menetapkan para penilik jemaat, diaken dan penatua di setiap jemaat yang mereka layani (1 Tim.1:18; Tit.1:5). Para penilik jemaat dan penatua inilah yang akan bertanggung jawab dalam setiap jemaat tersebut. Itulah sebabnya Paulus menuliskan surat kepada Timotius untuk memilih orang yang dapat dipercayai untuk mengajar dalam jemaat. Sejalan dengan itu Nainggolan menuliskan bahwa jemaat local membutuhkan kepemimpinan yang berkualitas yang dapat dan mampu merancang dan melaksanakan pendidikan terhadap warga jemaatnya. ${ }^{11}$ Itu artinya bahwa kompetensi Gembala sidang sebagai pengajar harus terus ditingkatkan secara maksimal agar dapat memberikan pertumbuhan iman dan kerohanian warga jemaat menuju kepenuhan hidup dalam Kristus.

Pelaksanaan tugas yang penuh tanggung jawab bagi Paulus patut mendapatkan tempat khusus dalam pandangan Timotius beserta jemaatnya. Paulus Lilik Kristianto, Gereja lokal memegang peran penting dalam mengajar Pendidikan Agama Kristen. Gembala sidang gereja lokal bertanggungjawab mendewasakan anggota jemaat.Gereja merupakan agen utama dalam mengajarkan Pendidikan Agama Kristen.Pengajaran PAK dapat diprogram melalui kebaktian umum, Sekolah Minggu, bible study, dan berbagai persekutuan kaum muda, kaum wanita dan kaum bapak. ${ }^{12}$ Itulah sebabnya Rasul Paulus dalam suratnya kepada Timotius agar memberi perhatian khusus pada para gembala sidang."Penatuapenatua yang baik kepemimpinannya patut dihormati dua kali lipat, terutama mereka yang dengan jerih payah berkhotbah dan mengajar (I Timotius

\footnotetext{
${ }^{10}$ Riggs, Gembala Sidang, 20

${ }^{11}$ J.M. Nainggolan, Strategi PAK, (Bandung: Generasi Info Media, 2008), 92

${ }^{12}$ Paulus Lilik Kristianto, Prinsip dan Praktik PAK, (Yogyakarta: ANDI, 2008), 7.
} 
5:17)."Gembala sidang yang berhasil adalah gembala sdiang yang selalu setia mendampingi serta membimbing anggota jemaat yang dercayakan Tuhan kepadanya untuk digembalakan sampai pada akhir hidupnya.

Sangat disayangkan memang karena tidak sedikit hamba Tuhan yang mengaku sebagai gembala sidang dan juga sebagai guru agama Kristen memperlakukan panggilan mereka itu seperti semacam suatu bentuk fatalisme. Artinya bahwa apapun yang akan terjadi akan terjadi bilamana terjadi. Ada juga pihak yang menganggap panggilan sebagai gembala sidang dan guru agama Kristen itu hanya karena mencoba-coba, mereka menganggap pelayanan tersebut sebagai sarana untuk menyalurkan hobby atau bakat serta kegemaran mereka. Di lain pihak ada yang melakukan pelayanan itu karena mereka mampu melakukannya secara materi sebagai indicator penopang pelayanannya. Yang lebih fatl algi adalah jika pelayanan ini dimanipulasi sedemikian rupa sebagai suatu permaian bisnis untuk mendapatkan keuntungan di dalamnya.Inilah fatalisme dalam pelayanan sehingga banyak pengajar agama Kristen tidak sampai pada tujuan dan hakekat pelayanan PAK itu sendiri.

Karena banyaknya penyalahgunaan atas panggilan ini, maka, adalah suatu hal yang tidak berlebihan jika Paulus memberikan syarat/kualifikasi bagi seorang penilik atau penatua (gembala), diaken untuk dijadikan pedoman bagi setiap hamba Tuhan sebelum mereka ditempatkan dalam suatu pelayanan.

\section{Gembala Sidang sebagai Pengajar}

Timotius dinasihati untuk tetap berpegang kepada ajaran yang Paulus teruskan kepadanya (1 Tim.1:3-11; 3:14-15).Juga dalam 2 Timotius Paulus menulis tentang 'harta yang indah, yang telah dipercayakan-Nya kepada kita' (1:14; bdk. 1:12). Dalam 2 Tim.1:8-10 Paulus menjelaskan secara ringkas kekayaan harta yang indah itu. Dasar kehidupan kristiani adalah apa yang telah Allah lakukan, bukan apa yang kita lakukan. Inilah yang menjadi acuan panggilan mengajar kita sebagai gembala sidang yang dipercayakan untuk mengembalakan domba-domba-Nya. Kita hanya dipanggil saja untuk 'live out the consequences of God's saving act' ('mempraktekkan dalam kehidupan sehari-hari akibat-akibat dari perbuatan Allah yang menyelamatkan') dalam kekuatan Allah (2 Tim.1:7). Inilah salah satu bagian dalam tridarma panggilan Gereja yakni, bersaksi (marturia). Dan ingat apa yang pesankan menjadi tugas utama para murid Yesus ketika Ia akan terangkat ke surga? Pesan-Nya adalah menjadi saksi Kristus sampai ke ujung-ujung bumi (Kis.1:8). Orang-orang Skeptis bertanya mengenai waktu menjadi bagi orang Kristen itu kapan? Sejak orang Kristen menjadi percaya kepada Yesus yang menjadi TUhan dan juruselamatnya, sejak saat itulah ia menjadi saksi Kristus.

Injil ini harus dipercayakan kepada orang-orang yang dapat dipercayai, yang juga cakap mengajar orang lain (2 Tim.2:2). Intisari Injil berlaku umum dan tidak berubah. Allah sendiri telah berfirman, 2 Tim.3:16-17! Tetapi itu bukan ortodoksi yang mati, tetapi dasar yang diletakkan Allah yang teguh (2 Tim.2:19). Injil Yesus Kristus yang diberitakan Paulus (1 Tim.2:6-7) adalah pusat kehidupan seluruh gereja kristiani.

Tujuan daripada penggembalaan adalah bagaimana membawa anggota jemaatnya dari tidak tahu membawa membaca, menjadi bisa membaca firman Tuhan; dari tidak tahu berdoa, menjadi bisa berdoa; dari tidak tahu berkhotbah, 
menjadi bisa berkhotbah; dari tidak tahu bersaksi, menjadi bisa bersaksi. Dengan demikian para anggota jemaat tidak akan gampang diombang ambingkan oleh rupa-rupa pengajaran sesat. Kennet 0 . Gangel, menyatakan bahwa, suatu pelayanan untuk membangun hubungan yang positif yang terhambat oleh kegagalan gembala sidang untuk berpartisipasi dalam program pendidikan gereja sebagai pusatnya. ${ }^{13}$

Jika ada gembala sidang tidak mengetahui persoalan apa yang sedang terjadi dalam jemaatnya, maka gembala sidang tersebut dikategorikan sebagai gembala sidang yang gagal. Indikator seorang hamba Tuhan adalah mengajarkan Firman Tuhan.Caranya bagaimana? Dengan cara berkhotbah (Sekolah Minggu, Pemuda, dan PW dan Umum), penginjilan, kunjungan, PA, Komsel dan persekutuanpersekutuan dalam gereja serta mengadakan pembinaan warga Gereja maupun dengan acara seminar. Oleh sebab itu menjadi gembala sidang adalah menjadi penunjuk jalan kepada kebenaran di dalam Kristus Yesus Kristus, agar mereka tahu jalan kepada keselamatan yang kekal itu dan mendapat serta memiliki selamanya.

Berikut ini apa yang disampaikan oleh Paulus kepada Timotius mengenai kriteria seorang gembala yakni penilik dan diaken yang bertanggung jawab dalam jemaatnya. Dengan melihat syarat yang diajukan oleh Paulus kepada Timotius ini merupakan hal yang sama juga dimiliki oleh seorang pengajar agama Kristen. I Timotius 3:2-12, memberikan definisi sebagai seorang penanggung jawab dalam jemaat baik itu sebagai penilik maupun sebagai diaken. Dengan memenuhi persyaratan ini, maka ia layak menggembalakan jemaat Tuhan.

\section{Kualifikasi pengajar agama Kristen}

Berdasarkan riset dalam I Timotius maka syarat bagi seorang gembala sebagai pengajar agama Kristen adalah sebagai berikut:

1. Tidak bercacat,

2. Suami dari satu isteri,

3. Dapat menahan diri,

4. Bijaksana,

5. Sopan,

6. Suka memberi tumpangan,

7. Cakap mengajar orang,

8. Bukan peminum,

9. Bukan pemarah melainkan peramah,

10. Pendamai,

11. Bukan hamba uang,

12. Seorang kepala keluarga yang baik,

13. Disegani dan dihormati oleh anak-anaknya.

14. Dapat mengurus Jemaat Allah? (I Tim. 3:5)

15. Janganlah ia seorang yang baru bertobat (I Tim. 3:6), agar jangan ia menjadi sombong dan kena hukuman Iblis.

\footnotetext{
${ }^{13}$ Kenneth O. Gangel, Membina Pemimpin Pendidikan Kristen, (Malang: Gandum Mas, 2001),
} 
16. Mempunyai nama baik di luar jemaat, agar jangan ia digugat orang dan jatuh ke dalam jerat Iblis (I Tim. 3:7).

Berikut juga kualifikasi seorang pengajar yang beorientasi pada pelayanan (diakonia) adalah sebagai berikut:

1. Haruslah orang terhormat,

2. Jangan bercabang lidah,

3. Jangan penggemar anggur,

4. Jangan serakah,

5. Dapat memelihara rahasia iman dalam hati nurani yang suci.

6. Mereka juga harus diuji dahulu, baru ditetapkan dalam pelayanan itu setelah ternyata mereka tak bercacat (I Tim. 3:10).

7. Demikian pula isteri-isteri hendaklah orang terhormat (I Tim. 3:11),

8. Jangan pemfitnah(I Tim. 3:11),

9. Hendaklah dapat menahan diri dan dapat dipercayai dalam segala hal(I Tim. 3:11).

10. Diaken haruslah suami dari satu isteri dan mengurus anak-anaknya dan keluarganya dengan baik (I Tim. 3:12).

Dengan demikian, tugas daripada seorang gembala sidang selaku pengajar adalah jelas sebagaimana dinyatakan dalam ayat di atas.Sangat disayangkan memang karena ada begitu banyak orang Kristen yang salah memahami hal ini.Mereka menyangka bahwa tugas gembala sidang itu hanya khusus berkhotbah di atas mimbar, sedangkan secara umum gembala sidang itu adalah sebagai penanggung jawab atas semua anggota jemaatnya.Harus dipahami bahwa dalam berkhotbah adalah merupakan suatu metode pengajaran Firman Tuhan.Maksudnya adalah bahwa dalam berkhotbah terdapat pengajaran Firman Tuhan, demikian juga dalam mengajarkan Firman Tuhan itu adalah khotbah.Antara berkhotbah dan mengajar memang berbeda namun tidak dapat dipisahkan.Mungkin dalam ilmu berkhotbah (homiletika) terdapat pemisahan secara spesifik, namun jika melihat pada pola pelayanan Yesus, hal itu sangat jelas dengan berbagai metode pelayanan-Nya.Inilah pola pelayanan yang dimaksudkan salah dipahami selama ini, yakni berkhotbah terlepas dari mengajar dan mengajar terlepas dari berkhotbah. Idealnya adalah kedua hal ini selalu berkaitan satu dengan yang lain.

Martin Luther (1483-1548) dalam tulisan Kristianto, PAK adalah pendidikan yang melibatkan warga jemaat untuk belajar teratur dan tertib agar semakin menyadari dosa mereka serta bersukacita dalam Firman Yesus Kristus yang memerdekakan. Di samping itu, PAK juga memperlengkapi mereka dengan sumber iman, khususnya yang berkaitan dengan pengalaman berdoa, Firman yang tertulis (Alkitab) dan rupa-rupa kebudayaan sehingga mereka mampu melayani sesamanya termasuk masyarakat dan Negara serta mengambil bagian dengan bertanggung jawab dalam persekutuan Kristen. ${ }^{14}$ Kualifikasi hamba Tuhan sebagai pengajar firman Tuhan hendaknya dibarengi dengan hati yang tulus dan setia kepada Tuhan. Dengan ketulusan dan kesetiaan dalam pelayanan khususnya dalam mengajar jemaat akan terus menerus berjalan dengan tiada digentarkan

\footnotetext{
${ }^{14}$ Kristianto, Prinsip dan Praktik, 2.
} 
oleh apapun selain karena Tuhan yang menyatakannya. Gembala sidang sebagai pengajar hendaknya memiliki kredibilitas, integritas dan dedikasi yang tinggi dalam pelayanannya. Dengan demikian dalam melaksanakan tugas pelayanannya akan nampak sebagai suatu persembahan yang hidup kepada Allah yakni gembala agung segala domba. Begitu banyak pelayan Tuhan saat ini yang melayani tetapi sebenarnya bukan melayani Tuhan, namun mereka melayani diri sendiri.Sematamata pelayanan itu mereka kerjakan karena tuntutan kebutuhan mereka bukan lagi karena hal itu adalah panggilan sorgawi dari Sang khalik Yesus Kristus.

10. Cakap mengajar (II Tim. 2:2,24-26)

Sebab itu, hai anakku, jadilah kuat oleh kasih karunia dalam Kristus Yesus.Apa yang telah engkau dengar dari padaku di depan banyak saksi, percayakanlah itu kepada orang-orang yang dapat dipercayai, yang juga cakap mengajar orang lain. sedangkan seorang hamba Tuhan tidak boleh bertengkar, tetapi harus ramah terhadap semua orang. Ia harus cakap mengajar, sabar dan dengan lemah lembut dapat menuntun orang yang suka melawan, sebab mungkin Tuhan memberikan kesempatan kepada mereka untuk bertobat dan memimpin mereka sehingga mereka mengenal kebenaran, dan dengan demikian mereka menjadi sadar kembali, karena terlepas dari jerat Iblis yang telah mengikat mereka pada kehendaknya.

Tugas ganda dari seorang gembala sidang adalah berkhotbah dan mengajar.Inilah yang disebut dengan pendidikan Agama Kristen.Pendidikan agama Kristen adalah pendidikan yang mencakup semua tema-tema yang terdapat dalam Alkitab. Di mana Alkitab berbicara tentang Allah, manusia, Kristus, Roh Kudus, Gereja, Akhir Zaman, Iblis, Malaikat, dosa dan Keselamatan. Di sinilah dituntut kecakapan mengajar seorang gembala sidang kepada anggota jemaatnya. Kecakapan mengajar tersebut merupakan modal utama sebagai seorang mentor atau pembimbing agama Kristen kepada anggota jemaatnya. Itulah sebabnya Paulus berpesan kepada Timotius untuk memberikan pengahrgaan dua kali lipat kepada mereka yang berkhotbah dan mengajar dalam jemaat (I Tim.5:17).

Dengan demikian Alkitab memuat pola atau tatanan hidup manusia dalam melangsungkan kehidupannya dalam dunia ini yang bersentuhan langsung dengan alam semesta dengan Tuhan Sang khalik.Itulah sebabnya Enklaar menjelaskan bahwa tanggung jawab seorang guru yang selaku gembala sidang adalah menjadi penafsir iman Kristen kepada yang diajarnya. Dialah yang menguraikan dan menerangkan kepercayaan Kristen itu, karena ia harus menyampaikan harta-harta dari masa lampau kepada para pemuda yang akan menempuh masa depan. ${ }^{15}$ Kompetensi spiritual yang dimiliki oleh Timotius juga dibarengi dengan kompetensi paidagogis yag ditempuhnya sejak kecil dalam keluarga menjadi nilai tambah baginya dalam pelayanan. Paulus mengatakan bahwa ia tidak sembarang saja meninju, namu ia punya perhitungan, artinya bahwa ia memiliki keyakinan yang sungguh sebagai pelayan Tuhan sehingga ia melangkah dengan pasti.

15 I.H. Enklaar \& E.G. Homrighausen, Pendidikan Agama Kristen, (Jakarta: BPK GM, 
Pendeta adalah seorang pengajar umum di jemaat. Di mana ia sendiri yang bertanggung jawab menentukan bagaimana jemaat menjadi persekutuan umat yang belajar mengajar. Pendeta adalah seorang pengajar khusus, dimana ia secara langsung mengajar; kelas katekesasi, teologi untuk warga jemaat, Ia berkhotbah di mimbar Gereja. ${ }^{16}$ Oleh sebab itu jika berbicara tentang pengajaran Firman Tuhan dalam jemaat, maka hal itu terletak pada tugas seorang gembala sidang. Penerapan pendidikan Agama Kristen dalam dilakukan di luar gereja jika sudah melalui proses yang baik dan benar dari pengajaran dan pendidikan yang diberlakukan dalam gereja setempat oleh gembala sidang.

Inilah yang dikemukakan oleh Oditha, bahwa pendidikan agama Kristen adalah usaha yang dilakukan secara terencana dan kontinu dalam rangka mengembangkan kemampuan siswa agar dengan pertolongan Roh Kudus dapat memahami dan menghayati kasih Allah di dalam kehidupan Yesus Kristus yang dinyatakan dalam kehidupan sehari-hari, terhadap sesama manusia dan lingkungan hidupnya. ${ }^{17}$ Dengan demikian, sistematisasi pendidikan agama Kristen yang diterapkan di gereja oleh gembala sidang akan memacu setiap anggota jemaat untuk terus tertanam, serta bertumbuh dan berbuah dalam Kristus di setiap jemaatnya (Kol. 2:6-7). Pertumbuhan jemaat yang sehat dan berkualitas adalah sangat ditentukan juga oleh asupan doktrin pengajaran yang benar dan alkitabiah dari seorang gembala sidang. Oleh sebab itu perlunya seorang gembala sidang itu terus belajar secara serius tentang kebenaran Firman Tuhan sehingga ketika ia mengajarkannya tidak akan ragu lagi. Sangat disayangkan karena saat ini amsih ada hamba Tuhan yang tidak mau berbenah untuk meng-upgrade pengetahuan mereka. Konsep kepemimpinan tradisional masih tetap melekat pada mind set mereka. Hanya karena tidak mau diajar oleh orang lebih muda dari mereka.

Gembala sidang sebagai pengajar menjadi guru bagi anggota jemaatnya. Enklaar menyatakan, bahwa sebagai guru ia bertanggung jawab atas hidup rohani mereka; ia wajib membina dan memajukan hidup rohani itu. ${ }^{18}$ Dengan pertumbuhan yang sehat akan memberi dampak positif pada buah yang merupakan hasil dari penerapan kebenaran Firman Tuhan tersebut. Sebagai hasil daripada penerapan kebenaran Firman Tuhan tersebut akan menghasilkan buah kebenaran pula. Dengan demikian tujuan pendidikan agama Kristen itu akan tercapai dengan baik. Apakah tujuan pendidikan agama Kristen itu?Tujuan pendidikan agama Kristen itu ada dua yakni; tujuan umum dan tujuan khusus.Lanjut Oditha menjelaskan bahwa, tujuan umum pendidikan agama Kristen itu adalah memperkenalkan Allah Bapa, Putera dan Roh Kudus beserta karyakarya-Nya.Kemudian menghasilkan manusia Indonesia yang mampu menghayati imannya secara bertangung jawab di tengah masyarakat yang pluralistic.Sedangkan tujuan khususnya adalah memperkenalkan nila-nilai kristiani dalam pribadi dan social siswa sehingga mampu menjadikan nilai kristiani sebagai acuan hidup personal maupun komunitas. ${ }^{19}$ Akhirnya nilai kekristenan dapat diterapkan di manapun dan dalam situasi apapun tanpa

${ }^{16}$ Eli Tanya, Gereja dan Pendidikan Agama Kristen (Cipanas, STT Cipanas, 1999), 98-99

17 Oditha R. Hutabarat, Pedoman Untuk Guru Pendidikan Agama Kristen SD-SMA dalam Melaksankan Kurikulum Baru, (Bandung: Bina Media Informasi, 2006), 10

${ }^{18}$ Enklaar \& Homrighausen, Pendidikan Agama Kristen, 165.

${ }^{19}$ Hutabarat, Pedoman Untuk Guru Pendidikan, 11 
terbeban oleh tekanan apapun.Inilah nilainya iman Kristen yang di ejahwantahkan oleh jemaat melalui pengajaran para gembala sidang yang berkompeten dalam pelayanannya."Di mana gurulah yang mengambil harta benda kabar kesukaan itu dari perbendaharaan gereja, lalu membagikannya kepada murid-muridNya." ${ }^{20}$ Inilah tugas gembala sidang yang juga berperan sebagai pengajar. Boehlke juga menyatakan bahwa sebagai guru, Firman itu menjelaskan serta menyatakan bahwa takut akan Tuhan, mengajar kita dalam pelayanan Allah, mendidik kita dalam pengetahuan kebenaran, dan membimbing dengan jalan yang menuju langsung ke sorga. ${ }^{21}$ Apa yang dinyatakan oleh Boehlke di atas ini bersama dengan pandangan Enklaar adalah merupakan tugas yang diemban oleh setiap pemimpin dalam gereja. Di mana tujuan pengajaran PAK dalam gereja senantiasa bermuara kepada pengenalan akan Kristus, Bapa dan Roh Kudus selanjutnya dituntun untuk terlibat dalam pelayanan. Paulus memberikan tugas ini juga kepada Timotius dan Titus dengan tujuan untuk mengajarakan kebenaran Firman Tuhan kepada jemaat dan untuk mampu menghadapi gangguan ajaran sesat yang berkembang saat itu.

\section{Gembala Sidang sebagai Pengajar menurut surat Titus}

Titus adalah seorang bukan Yahudi yang sudah masuk agama Kristen lalu menjadi teman sekerja dan pembantu Paulus dalam pekerjaannya. Surat ini ditujukan kepada Titus yang pada waktu itu berada di Kreta karena telah ditinggalkan di sana oleh Paulus untuk mengurus jemaat di sana. Ada tiga hal yang dikemukakan di dalam surat ini.

Pertama, Titus diingatkan mengenai sifat-sifat orang yang boleh menjadi pemimpin jemaat. Hal itu dikemukakan terutama karena kelakuan orang-orang di Kreta banyak yang jahat. Kedua, Titus dinasihati mengenai bagaimana seharusnya ia mengajar setiap golongan orang yang menjadi anggota jemaat itu, yaitu golongan laki-laki dan wanita yang sudah tua (yang seharusnya mengajar pula orang-orang yang lebih muda dari mereka), golongan orang-orang muda, dan golongan hamba-hamba. Akhirnya Titus diajar mengenai bagaimana seharusnya kelakuan orang Kristen.Yang paling penting ialah bahwa orang Kristen harus peramah dan suka damai, jangan membenci orang, jangan suka bertengkar atau menimbulkan perpecahan.

Begitu juga dengan para Penatua yang disebut dalam Titus 1:5-9 harus diajar lebih dahulu, dan kemudian harus berpegang kepada Firman Allah yang benar. ${ }^{22}$ Dengan mengajar para penatua terlebih dahulu, maka apa yang telah mereka terima akan mereka bagikan juga dalam pelayanan mereka ke depan. Harapan tongkat estafet kepengajaran menjadi terlaksana dengan baik dan benar dalam jemaat.

Tugas Titus sebagai gembala sidang di pulau Kreta selain menetapkan para penatua di sana ia juga diberi tugas untuk terus mengajarkan ajaran yang sehat (Tit. 2:1). Dengan demikian sebagai gembala sidang dapat menjadi teladan dalam segala hal karena niat baik serta kesungguhan hati dalam pengajaran akan

\footnotetext{
${ }^{20}$ Enklaar \& Homrighausen, Pendidikan Agama Kristen, 164

${ }^{21}$ Robert R. Boehlke, Sejarah Perkembangan Pikiran dan Praktek Pendidikan Agama Kristen, (Jakarta: BPK GM., 2008), 104

${ }^{22}$ Riggs, Gembala Sidang, 19
} 
memberi dampak yang baik dalam pelayanan (Tit.2:6-8). Itulah sebab rasul Paulus menuliskan kepada Titus supaya memilih dan menetapkan para penatua yang memiliki kriteria sebagai seorang penatua (Tit.1:5-9).

Gembala dan pengajar-pengajar ini sangat penting dalam pertumbuhan kita sebagai orang Kristen.Karena mereka khusus diangkat oleh Tuhan guna mengajar, membimbing anak-anak Tuhan untuk bertumbuh dengan berlandaskan pada Firman Tuhan. Di sinilah letak pentingnya para gembala, pendeta, pengajar, karena mereka dapat menunjukkan relevansi Firman Tuhan yang begitu kaya tentang bagaimana caranya hidup bertumbuh dan lebih baik dari hari ke hari, dan tidak ada area kehidupan yang tidak disentuh oleh Alkitab mulai dari relasi kita dengan Tuhan dan relasi kita dengan sesame dan berkarya dan hidup berkemenangan.

Para gembala adalah orang yang diutus Tuhan untuk memperlengkapi anakanak Tuhan untuk bertumbuh dalam segala aspek hidup ke arah Kristus (Efesus 4 ayat: 15). Mereka mengarahkan dan memperlengkapi kita, supaya kita berhasil dalam pertumbuhan kita sebagai anak-anak Tuhan.

\section{Kualifikasi seorang pengajar menurut Titus}

Nainggolan menyatakan dalam buku Strategi Pendidikan Agama Kristen bahwa, sebagai orang Kristen, guru terpanggil untuk bertumbuh kea rah pengenalan yang semakin mendalam dan lengkap tentang pribadi Yesus Kristus, selanjutnya kebenaran yang harus dikejar oleh guru Kristen adalah kebenaran realistis yaitu yang nyata dalam kehidupan. ${ }^{23}$ Jadi sebelum mereka mengajar dan berkhotbah tentang Firman Tuhan, para guru dan gembala harus terlebih dahulu menghidupi dan mengalami sendiri apa yang akan diajarkan dan dikhotbahkan nanti. Sebagai bahan acuan bagi pelayanan setiap gembala sidang, maka berdasarkan Alkitab berikut ini dipaparkan oleh Paulus kepada Titus. Adapun persyaratan atau kualifikasi sebagai seorang pemimpin dalam jemaat adalah sebagai berikut:

1. Orang-orang yang tak bercacat,

2. Mempunyai hanya satu isteri, yang anak-anaknya hidup beriman dan tidak dapat dituduh karena hidup tidak senonoh atau hidup tidak tertib.

3. Sebab sebagai pengatur rumah Allah seorang penilik jemaat harus tidak bercacat,

4. Tidak angkuh,

5. Bukan pemberang,

6. Bukan peminum,

7. Bukan pemarah,

8. Tidak serakah,

9. Suka memberi tumpangan,

10. Suka akan yang baik,

11. Bijaksana,

12. Adil,

13. Saleh,

14. Dapat menguasai diri

${ }^{23}$ Nainggolan, Strategi Pendidikan, 53 
15. Berpegang kepada perkataan yang benar, yang sesuai dengan ajaran yang sehat, supaya ia sanggup menasihati orang berdasarkan ajaran itu dan sanggup meyakinkan penentang-penentangnya. Karena sudah banyak orang hidup tidak tertib, terutama di antara mereka yang berpegang pada hukum sunat. Dengan omongan yang sia-sia mereka menyesatkan pikiran.

Peran penting seorang gembala sidang adalah untuk memberikan pengajaran yang sehat dan baik kepada seluruh anggota jemaatnya.Bahaya kesesatan dalam jemaat perlu diwaspadai oleh setiap pemimpin jemaat. Dengan demikian setiap pengajaran yang tidak sehat akan terbendung oleh pengajaran yang sehat dari gembala sidang yang terpelajar. Gembala sidang sebagai pengajar adalah bertugas untuk memberikan arahan, bimbingan dan tuntunan kepada anggota jemaatnya. Homrighausen dalam Nainggolan menuliskan tanggung jawab guru sebagai pengajar demikian;

Guru menjadi penafsir iman Kristen. Jadi gurulah yang menguraikan dan menerangkan kepercayaan Kristen. Guru menjadi seorang gembala bagi murimuridnya. Artinya ia bertanggung jawab atas hidup rohani mereka dank arena itu ia wajib membina dan memajukan hidup rohani itu. Ketiga, guru juga harus menjadi seorang pedoman dan pemimpin, ia tidak boleh menuntu muridnya masuk ke dalam kepercayaan Kristen dengan paksaan, melainkan ia harus membimbing mereka dengan halu dan lemah lembut kepada juruselamat. ${ }^{24}$

Baik Timotius maupun Titus keduanya merupakan anak rohani rasul Paulus dalam pelayanan. Keduanya telah diperlengkapi oleh Paulus dalam pelayanan sebelumnya sehingga ketika Paulus menempatkan mereka untuk melayani pada daerah tertentu, mereka sudah mampu melaksanakannya sendiri. Nainggolan menjelaskan bahwa seorang guru harus mempunyai pengetahuan yang cukup tentang isi iman Kristen.Ia harus mengenal dengan baik Alkitab. Untuk itu ia sendiri pun perlu dididik dan dilatih sebelum mengajar. ${ }^{25}$ Inilah dasar kualifikasi seorang gembala sidang yang juga sekaligus sebagai pengajar jemaat seperti apa yang ditegaskan oleh Paulus kepada Timotius dan Titus.

Sebagaimana diketahui bahwa tugas daripada gembala adalah untuk memberitahukan Firman Tuhan, maka demikian pula kiranya dengan pengajaran yang dikerjakan secara bersamaan ketika berkhotbah sudah terdapat pengajaran.Peran kepemimpinan gembala sidang dalam pelayanan yang berorientasi pada pemuridan merupakan kunci sukses suatu penggembalaan.

\section{HASIL}

Sebagai hasil dari penelitian ini dapat dijadikan impilikasi bagi gembala sidang dan pendidik Kristen masa kini, maka ada beberpa hal yang harus diperhatikan. Berikut ini adalah beberapa syarat yang harus dimiliki oleh seorang gembala sidang. Pertama harus memiliki pengetahuan mengenai diri sendiri. ${ }^{26}$

\footnotetext{
${ }^{24}$ Nainggolan, Strategi Pendidikan, 53

${ }^{25}$ Nainggolan, Strategi Pendidikan, 65

${ }^{26}$ Wongso,Theologia Penggembalaan, 18
} 
Waterhouse, seperti dikutip oleh Wongso mengatakan; Sebelum menanyakan pelayanan, bakat, pendidikan dari seorang pendeta, lebih baik kita bertanya mengenai kepribadian orang tersebut, sebab kepribadianlah yang menentukan pelayanannya. ${ }^{27}$

Lebih lanjut Wongso menjelaskan bahwa orang yang sudah mengnal dirinya sendiri mampu menguasi diri dan bertindak dengan bijaksana, karena dia tahu mengapa , bagaimana, kapan di mana dia mengerjakan sesuatu dan apa yang harus dikerjakannya.

Syarat kedua, adalah mengenal kebutuhan orang lain. Jika seorang pendeta sudah mengenal diri sendiri dengan baik, maka dia harus juga mengenal orang lain dengan baik. Jika tidak Ia seperti pemanah yang ahli tetapi tidak mempunyai sasaran. Jadi mengenal diri sendiri dan orang lain adalah dua sisi mata uang.

Hal-hal yang perlu diperhatikan adalah mengenal kebutuhan, mengetahui perbedaan dan menyadari adanya faktor lingkungan. Sebuah perbedaan muncul karena adanya kebutuhan yang berbeda yang disebabkan salah satunya oleh faktor lingkungan. Dengan menyadari ketiga hal ini, maka seorang pendeta dapat mulai mengenal orang lain.

Ketiga, seorang pendeta harus mengetahui kebutuhan polok manusia. Wongso mendaftarkan dengan lengkap berbagai kebutuhan tersebut. Selain diakui, semua kebutuhan tersebut harus diakomodasi dan dikontrol dalam pemenuhannya. Dengan melakukan ketiga hal tersebut maka seorang gembala sidang sedang mengakui keberadaan orang yang dibimbingnya.

Yang terakhir, seorang gembala sidang harus menyadari bahwa setiap orang mempunyai cara-cara yang berbeda dalam menyikapi kehidupan. Cara-cara ini merupakan refleksi dari kepribadian yang berbeda-beda. Hipocrates ${ }^{28}$ mendaftarkan empat macam kepribadian: sanguine, choleric, menalcholic dan phlegmatic. Sedangkan Karl Jung ${ }^{29}$ hanya mendaftarkan tiga jenis kepribadian: introvert, ekstrovert dan ambibert. Pada dasarnya, bagaimanapun juga pembagian yang diusulkan oleh para ahli, mereka sedang mengakui bahwa ada perbedaan dasar dalam diri manusia yang menimbulkan tanggapan-tanggapan yang berbeda terhadap kehidupan.

Sebagai implikasi bagi para gembala sidang dan pendidik Kristen dalam penelitian ini akan dipaparkan beberapa hal yang meliputi: Pertama, menunjukkan kepada jemaat Tuhan mengenai kebenaran Firman Tuhan tentang bagaimana orang Kristen harus hidup, bersikap dalam hidup baik kehidupan pribadi, keluarga, pekerjaan dan berjemaat, bermasyarakat

Kedua, menunjukkan kebenaran Firman Tuhan bahwa Firman Tuhan memberikan solusi atas setiap pergumulan anak-anak Tuhan di dalam kehidupan mereka. Pada saat ini ada kehausan yang luar biasa dimana-mana tentang Firman Tuhan, anak-anak Tuhan, baik muda maupun tua, mereka mencari solusi kehidupan yang tidak dapat ditawarkan oleh dunia. Para pengajar, pendeta baik dalam maupun luar negeri banyak yang megadakan seminar-seminar dan mengarang buku yang menjelaskan secara sederhana mengenai relevansi Firman Tuhan dengan persoalan keseharian anak-anak Tuhan

\footnotetext{
${ }^{27}$ Wongso,Theologia Penggembalaan, 18

${ }^{28}$ Wongso,Theologia Penggembalaan., 37

${ }^{29}$ Wongso,Theologia Penggembalaan. 38
} 
Ketiga, mengarahkan anak-anak Tuhan kearah pertumbuhan dan kedewasan penuh yang mendorong anak-anak Tuhan untuk bertumbuh sehingga mencapai kedewasaan penuh. Tetapi bagaimanapun tanpa kerjasama dari jemaat, para gembala ini tidak dapat bekerja melakukan tugasnya dengan baik. Pertanyaannya sekarang apakah kita sebagai jemaat telah melakukan bagian kita agar para gembala dapat melakukan tugas mereka dengan baik? Untuk mendukung tugas para gembala sidang sebagai pengajar paling tidak ada beberapa yang harus diperhatikan: (1) menghormati mereka sebagai utusan-utusan Tuhan (ambasador of God). Kalau menghormati yang mengutus, tentu juga akan menghormati orang yang diutus; (2) mempraktekan pengajaran yang mereka berikan dalam proses pembaharuan yang dilandaskan pada Firman Tuhan; dan (3) menaati perintah Tuhan untuk menyalurkan berkat Tuhan guna mencukupkan kesejahteraan para pendeta dan keluarganya. Tuhanlah yang mencukupkan keperluan mereka melalui berkat yang diberikan Tuhan kepada kita.

Keempat, menhagarahkan hidup pada janji Tuhan yang menjamin akan menyertai dalam pelayanan sebagai hamba Tuhan. Perintah Tuhan ini antara lain disebutkan dalam 1). Maleakhi 3: 10 yang mengatakan "Bawalah seluruh persembahan persepuluhan itu ke dalam rumah perbendaharaan, supaya ada persediaan makanan di rumah-Ku dan ujilah Aku, firman TUHAN semesta alam, apakah Aku tidak membukakan bagimu tingkap-tingkap langit dan mencurahkan berkat kepadamu sampai berkelimpahan.” Dan 2) 1 Korintus $9: 7$ yang berbunyi "Siapakah yang pernah turut dalam peperangan atas biayanya sendiri? Siapakah yang menanami kebun anggur dan tidak memakan buahnya? Atau siapakah yang menggembalakan kawanan domba dan yang tidak minum susu domba itu?" Dan pada ayat 14 dikatakan "Demikian pula Tuhan telah menetapkan, bahwa mereka yang memberitakan Injil, harus hidup dari pemberitaan Injil itu." Dengan kerjasama yang baik antara jemaat dan gembala, salah satu tugas gembala untuk melengkapi anak-anak Tuhan dalam pembaharuan terus menerus sehingga kita bertumbuh ke arah Kristus dalam segala hal!

\section{E. KESIMPULAN}

Dalam menghadapi tantangan pelayanan yang besar dalam era informasi atau purnamodern ini para pemimpin gereja tidak boleh terhanyut pada tujuan yang sesat, hanya mencari popularitas, keuntungan materi, atau kepentingan pribadi.Falsafah dan peran kepemimpinan Kristen masa kini haruslah dibangun berdasarkan prinsip Alkitab dan dengan memperhitungkan tantangan zaman ini.Ada beberapa prinsip yang dapat menjadi pedoman bagi kepemimpinan Kristen masa kini.

Pertama, wibawa kepemimpinan berdasarkan karakter yang baik. Dalam I Tim 4:12 Paulus menasehati Timotius, "Jangan seorangpun menganggap engkau rendah karena engkau muda."Paulus menasehati demikian karena Timotius gembala yang relatif muda (30-40 tahun) atau penakut. Sebaliknya ia harus memenangkan hormat jemaat dengan cara menjadi teladan atau memiliki kepribadian/karakter yang benar, bukan melalui gelar akademis, tipu muslihat atau cara lain. Adanya kriteria bagi para pemimpin gereja juga menegaskan prinsip ini (I Tim. 3:1-13). 
Kedua, menjadi teladan bagi orang-orang percaya. Pemimpin gereja tidak mungkin orang yang sempurna, namun ia dapat menjadi teladan bagi warga jemaat. Menurut ayat di atas keteladanan itu dalam perkataan, tingkah laku (dalam arti luas), kasih, kesetiaan, kesucian (bukan hanya dalam hal seksualitas, tapi juga kesucian dan integritas hati, serta tingkah laku). Prinsip keteladanan ini sangat ditekankan Paulus (I Kor. II:1; Fil. 3:17). Ini merupakan prinsip pemuridan yang fundamen dalam kekristenan.Dapatkah seorang pemimpin gereja mengajar dan mempengaruhi jemaat jika teladannya tidak bersesuaian dengan ajarannya?Itu sebabnya mengapa mengawasi diri tidak terlepas dari mengawasi ajaran (I Tim. $4: 16)$.

Ketiga, menjadi komunikator kebenaran. Paulus menasehati agar Timotius bertekun dalam membaca Alkitab, membangun dan mengajar (I Tim 4:13).Ini merupakan tugas publik Timotius dan menjadi jalan untuk menghadapi ajaran sesat pada saat itu (2 Tim. 3:14-17).Mengajar merupakan tugas yang penting bagi pemimpin gereja di dalam era informasi ini.Sebab melaluinya worldview dan doktrin yang benar dapat ditanamkan dalam kehidupan jemaat, penyesatan dapat ditangkal, informasi yang membingungkan dan menyesatkan dapat dihadapi dengan sehat.

Keempat, menggembalakan jemaat. Tanggung jawab utama para pemimpin gereja adalah menggembalakan jemaat Tuhan (1 Ptr. 5:3).Ini berarti memperhatikan kesejahteraan rohani jemaat agar mereka dapat hidup dalam ketaatan kepada kehendak Allah. Keadaan zaman ini memungkinkan banyak orang tersesat dan harus dibimbing menerima Yesus, orang yang lemah iman perlu dikuatkan, keluarga yang dilanda problema perlu dibimbing mendapatkan kemenangan, dan masih banyak problema lain yang menuntut tanggung jawab penggembalaan dari gembala jemaat.

Kelima, mengenal nilai dan arah zaman. Para pemimpin gereja harus memimpin dan menggembalakan warga jemaat menuju tujuan sebagaimana yang dikehendaki Tuhan bagi gerejaNya.Di samping memiliki kehidupan yang benar dan setia kepada firman Tuhan, para pemimpin gereja patut mengenal nilai dan arah zamannya. Dengan kata lain, memiliki sensitivitas terhadap kebudayaan zamannya. Pengenalan ini akan membantu pemimpin gereja merumuskan dan mempertajam visi pelayanan dan meningkatkan efektivitas penginjilan di tengah zamannya. Ini berimplikasi bahwa para pemimpin gereja secara progresif terus meningkatkan kualitas kerohanian dan wawasannya.

Keenam, membangun pelayanan yang berdasarkan kerjasama tim. Dalam era globalisasi yang multi tantangan ini mustahil seorang pemimpin sanggup memikul seluruh tanggung jawab seorang diri saja.Zaman ini tidak memerlukan kepemimpinan yang hanya mengandalkan figur dan kharisma seorang pemimpin saja.Tantangan yang besar dan berdimensi luas harus diatasi melalui kerjasama di antara para pemimpin gereja, antara pemimpin dan warga jemaat, dan antar warga jemaat sendiri.Sudah saatnya orang Kristen melayani sebagai suatu jejaring kerja yang luas di tengah dunia ini. 


\section{Bibliografi}

ALKITAB, Jakarta: Lembaga Alkitab Indonesia, 1976

Sidjabat, B.S., Menjadi Guru Profesional, (Bandung: Kalam Hidup, 2000)

S.S, Daryanto, Kamus Bahasa Indonesia Lengkap, (Surabaya: Apollo, 1997)

Tanya, Eli, Gereja dan Pendidikan Agama Kristen, (Cipanas, STT Cipanas, 1999)

Enklaar, I.H. \& Homrighausen, E.G., Pendidikan Agama Kristen, (Jakarta: BPK GM, 2011)

Nainggolan, J.M., Strategi PAK, (Bandung:Generasi Info Media, 2008)

Gangel, Kenneth O., Membina Pemimpin Pendidikan Kristen, (Malang: Gandum Mas, 2001)

Hutabarat, Oditha R., Pedoman Untuk Guru Pendidikan Agama Kristen SD-SMA dalam Melaksankan Kurikulum Baru, (Bandung: Bina Media Informasi, 2006)

McMahan, Oliver, Gembala Jemaat yang Sukses, (Jakarta : Sinode GBI, 2002)

Kristianto, Paulus Lilik, Prinsip dan Praktik PAK, (Yogyakarta:ANDI, 2008)

Wongso, Peter, Theologia Penggembalaan, (Malang: Literatur SAAT, 2007)

Riggs, Ralph M., Gembala Sidang Yang Berhasil, (Malang:Gandum Mas, 2003)

Boehlke, Robert R., Sejarah Perkembangan Pikiran dan Praktek Pendidikan Agama Kristen, (Jakarta: BPK GM., 2008)

Tim Penyusun, KBBI-III, (Jakarta: Balai Pustaka, 2002)

Groome, Thomas H., Christian Religious Education. Jakarta: BPK Gunung Mulia, 2011

Tung, Khoe Yao, Terpanggil Menjadi Pendidik Kristen yang Berhati Gembala, Yogyakarta: ANDI, 2016 